\title{
Design of Green Tax System Plan for China's Automobile Products and Evaluation on Environmental Benefits
}

\author{
Lulu Huo ${ }^{1, *}$, Yonghe Huang ${ }^{1}$, Kexin Liu $^{1}$, Hong Shi ${ }^{1}$, Bin Liu ${ }^{1}$ \\ ${ }^{1}$ China Automotive Technology \& Research Center Co., Ltd., China
}

\begin{abstract}
The green tax system includes various taxation measures implemented for the purpose of environmental protection and has been widely adopted in developed countries. Based on the basic situation of China's tax system for automobiles, this article proposes a green tax system plan for China's automobile products from 2021 to 2035 in accordance with the basic principles of tax neutrality, environmental protection priority, tax system flexibility and orderly progress. In addition, this article uses the nested multi-logit model to predict the impact of the plan on the structure of vehicle market and finally conducts comprehensive evaluation on the environmental benefits of the plan by combining with the changes in energy consumption level, mileage of passenger vehicles, pollutant emissions of a single vehicle and other factors.
\end{abstract}

\section{Instruction}

Broadly speaking, the green tax system includes various taxation measures implemented for the purpose of environmental protection.

As an industry that plays a pivotal role in economic and social development, the automobile industry has a long industrial chain, a high degree of relevance and a wide range of areas. It spans major end-use energy sectors including industry, transportation and construction, so it has greater pressure from energy conservation and emission reduction. In order to accelerate the promotion of carbon emission reduction targets for automobile industry, automobile tax systems based on energy efficiency and other indicators have been established in Europe, the United States and Japan. For example, European and American countries generally use $\mathrm{CO} 2$ emissions or fuel consumption values as tax basis, while Japan sets phased fuel consumption targets for the industry and gives tax deductions or exemptions to the vehicles having achieved their goals early.

China's automobile excise tax and vehicle and vessel tax are based on engine displacement, and both excise tax and vehicle purchase tax are ad valorem taxes. Thus, present tax system fails to play a guiding role in energy conservation and emission reduction in the automobile industry. The goal of carbon peak and carbon neutrality puts forward higher requirements for the development of the automobile industry at present and for a period of time in the future. It will be more important for tax to play the regulatory role. The development of energy-saving and new energy vehicles should be further accelerated through the establishment of the green tax system for automobile products, so as to promote the realization of low-carbon development goals in the automobile industry.

\section{Ideas about policies}

\subsection{Principles}

- Principle of tax neutrality: The adjustment to tax system should not interfere with the operation of the industry. The adjustment should be based on current tax system, no new taxes will be added, and the overall balance of automobile taxation should be guaranteed.

- Principle of environmental protection priority: The green tax system should consider its orientation of energy saving and emission reduction in the design of tax system and incorporate energy efficiency indicators.

- Principle of tax flexibility: The tax system should set up a dynamic adjustment mechanism, which should be adjusted flexibly and appropriately by the factors such as industrial scale, technological level and macroeconomic environment.

- Principle of orderly promotion: The design of the tax system should be implemented step by step by combining long goals with short goas.

\subsection{Design of tax system}

\subsubsection{Overall framework}

To ensure the overall balance of automobile taxation and to maintain the current tax system in basically stable, the design of green tax system can refer to Japan's green tax system for automobile products. Based on the current automobile tax system, the role of existing taxes on energy conservation and environmental protection should be improved and no new taxes or progressive reform to the tax system will be proposed. At the same time, considering

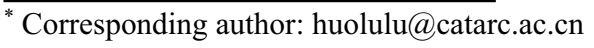


that passenger cars are mainly for private consumption and the tax adjustment has more obvious effect, the design of tax system can focus on passenger car products.

\subsubsection{Selection of tax types}

Currently, the main types of taxes levied on automobile products in China include tariff, excise tax, value-added tax, vehicle purchase tax, vehicle and vessel tax. The green tax system involves preferential choice of vehicle purchase tax and excise tax.

- From the perspective of the scope of tax object, the vehicle purchase tax is mainly levied on automobile products. Its system is relatively simple, and the reform will be more operable. There is a separate tax item for automobiles in the excise tax and one of the purposes of levying the excise tax is to regulate consumption. It is more reasonable to strengthen its orientation in energy conservation and emission reduction.

- From the perspective of tax amount, vehicle and vessel tax is levied on an annual basis, but most passenger cars have a relatively low annual tax amount. The adjustment influence on it will be limited.

- From the perspective of relationship between price and tax, the excise tax is included in the car price, and the vehicle purchase tax is paid directly by consumers. Reforms on these two types of taxes have more obvious regulatory effects.

\subsubsection{Selection of energy-saving and emission- reduction indicators}

At present, China has formulated, released and implemented a series of important standards related to

Table 1. Green tax system for passenger car products in the period of 2021-2035.

\begin{tabular}{|c|c|c|c|c|}
\hline Year & Pol & cy plan & Vehicle purchase tax & Excise tax \\
\hline \multirow{2}{*}{$\begin{array}{l}2021- \\
2022\end{array}$} & \multirow{2}{*}{$\begin{array}{l}\text { Present policies. } \\
\text { Based on model and power } \\
\text { type }\end{array}$} & $\begin{array}{l}\text { BEV } \\
\text { FCEV }\end{array}$ & $100 \%$ discount & $100 \%$ discount \\
\hline & & PHEV & $100 \%$ discount & No discount \\
\hline \multirow{2}{*}{$\begin{array}{l}2023- \\
2024\end{array}$} & \multirow{2}{*}{$\begin{array}{l}\text { Present policies reduction. } \\
\text { Based on model and power } \\
\text { type }\end{array}$} & $\begin{array}{l}\text { BEV } \\
\text { FCEV }\end{array}$ & $50 \%$ discount & $100 \%$ discount \\
\hline & & PHEV & $50 \%$ discount & No discount \\
\hline \multirow[t]{2}{*}{2025} & \multirow{2}{*}{$\begin{array}{l}\text { Present policies reduction. } \\
\text { Based on model and power } \\
\text { type }\end{array}$} & $\begin{array}{l}\text { BEV } \\
\text { FCEV }\end{array}$ & $25 \%$ discount & $100 \%$ discount \\
\hline & & PHEV & $25 \%$ discount & No discount \\
\hline \multirow{2}{*}{$\begin{array}{l}2026- \\
2030\end{array}$} & \multirow{2}{*}{$\begin{array}{l}\text { Implement preferential } \\
\text { policies based on fuel } \\
\text { consumption. } \\
\text { No excise tax levied on BEVs } \\
\text { and FCEVs }\end{array}$} & $\begin{array}{l}\text { BEV } \\
\text { FCEV }\end{array}$ & $25 \%$ discount & $100 \%$ discount \\
\hline & & $\begin{array}{l}\text { Reach the fuel consumption target } \\
4 \text { years ahead of schedule }\end{array}$ & Reduce $25 \%$ & Reduce $10 \%$ \\
\hline \multirow{2}{*}{$\begin{array}{l}2031- \\
2035\end{array}$} & \multirow{2}{*}{$\begin{array}{l}\text { Tighten preferential policies } \\
\text { based on fuel consumption. } \\
\text { Excise tax levied on BEVs } \\
\text { and FCEVs }\end{array}$} & $\begin{array}{l}\text { Reach the fuel consumption target } \\
5 \text { years ahead of schedule }\end{array}$ & Reduce $25 \%$ & Reduce $10 \%$ \\
\hline & & $\begin{array}{l}10 \% \text { higher than the target value of } \\
\text { fuel consumption for the year }\end{array}$ & Add 10\% & Add $10 \%$ \\
\hline
\end{tabular}

automobile fuel consumption test methods, limits and labels, and has established a relatively complete passenger car fuel consumption standard system. There is a certain foundation for the inclusion of vehicle fuel consumption indicators in the automobile tax system.

The fuel consumption indicators for passenger cars per $100 \mathrm{~km}$ can be added in the original tax system. Tax incentives are given based on the fact that passenger vehicle products reach the target value of fuel consumption in advance. Then, with the development of new energy vehicles, electricity consumption and other indicators would be gradually incorporated.

\subsubsection{Policy implementation steps}

Tax reform should combine long goals with short goals and effectively integrate with existing policies. From 2021 to 2025 , the existing vehicle purchase tax exemption policy will be moderately reduced, while the research on tax incentives based on passenger vehicle fuel consumption indicators will be carried out. After 2026, tax incentives based on fuel consumption will be implemented, while a dynamic adjustment mechanism for preferential policies will be established and adjusted in accordance with fuel consumption regulations. And the policies will be further tightened from 2031 to 2035 .

\subsubsection{Specific reform plan}




\section{Evaluation on the effects of implementing the policies.}

\subsection{Evaluation ideas}

- Based on the current vehicle purchase tax rate and preferential policies, combine with the fuel consumption level of various passenger vehicles in 2018, and calculate the comprehensive tax rate of the consumption tax and vehicle purchase tax levied on passenger vehicles under the green tax system.

Construct a passenger car market penetration model, combine the differences in comprehensive tax rates in different policy scenarios, predict the sales of various models in the market from 2021 to 2035 and evaluate the impact of policies on the market.

- Calculate and estimate energy conservation and environmental protection effects based on sales volume and evaluate the driving effects of policies on energy conservation and environmental protection.

\subsection{Calculation and estimate of comprehensive tax rate.}

Combining the actual ratio of passenger vehicles of different types to reach the target value of fuel consumption from 2016 to 2020 and the specific design plan for tax system, the comprehensive tax rate of vehicle purchase tax and consumption tax is calculated by the weighted average method for five types of vehicles including ICV, HEV, BEV, PHEV and FCEV in the period of 2021-2035, as shown in Table 2.

Table 2. Comprehensive tax rates of vehicle purchase tax and consumption tax for passenger car products in the period of 2021-2035.

\begin{tabular}{|c|c|c|c|c|c|}
\hline Year & ICV & HEV & BEV & PHEV & FCEV \\
\hline $2021-2022$ & 14.0 & 14.0 & 0.0 & 4.0 & 0.0 \\
\hline $2023-2024$ & 14.0 & 14.0 & 5.0 & 9.0 & 5.0 \\
\hline 2025 & 14.0 & 14.0 & 7.5 & 11.5 & 7.5 \\
\hline $2026-2030$ & 14.1 & 13.7 & 7.5 & 11.5 & 7.5 \\
\hline
\end{tabular}

\subsection{Forecast for the impact on sales.}

In order to realize the forecast for the overall passenger car market space and sales proportion of each model in the future, this article constructs a passenger car market penetration model, which is divided into two parts including inventory module and market penetration rate module. The overall passenger car market space, annual sales trends and model market share are forecast by using each module. These two parts are combined to get the forecast for market sales of each model, which can provide a basis for evaluating the development trend of various vehicle models in the future under the background of the green tax scheme.

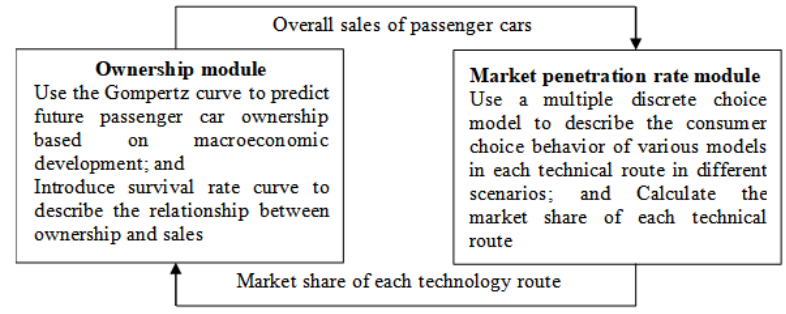

Fig. 1. Passenger car market penetration model flowchart.

The research assumes that consumers mainly consider the five-year comprehensive cost of each model in the decision-making process of purchasing a passenger car. At the same time, different tax increase plans are set for different technical routes in terms of purchase cost. In this research, the nested multivariate logit model is used to predict the probability of consumers choosing each model under different tax plans, so as to obtain the forecast form the market share of each model in the passenger car market and effect of implementing green tax scheme.

Combining the laws of macroeconomic and market development, the long-term sales trend of passenger vehicles will continue to rise steadily. And with the gradual increase in the replacement proportion in the passenger car market, the overall growth rate will stabilize, with an average annual growth rate about $2 \%$. It is estimated that the overall passenger car market sales will be close to 30 million units by 2035 .

Taking the changes in purchase costs brought about by technological upgrades of various models and increase in compliance costs of fuel vehicles caused by stricter fuel consumption regulations into account, it is predicted that the proportion of NEV (new energy vehicles) sales in $2025 / 3030 / 2035$ will reach respectively $12.5 \% / 32.5 \%$ $141.2 \%$ under basic scenarios.

Under the background of implementing the green tax scheme, the sales volume of NEV is expected to exceed 3.3 million and the market share will increase to $14.1 \%$ in 2025; in 2030, the advantages of NEV will be further revealed, the sales volume is expected to exceed 9 million vehicles and the market share will increase to $35.0 \%$; in 2035, the scale of NEV market is expected to be close to 13 million vehicles and the market share will increase to $47.0 \%$. 

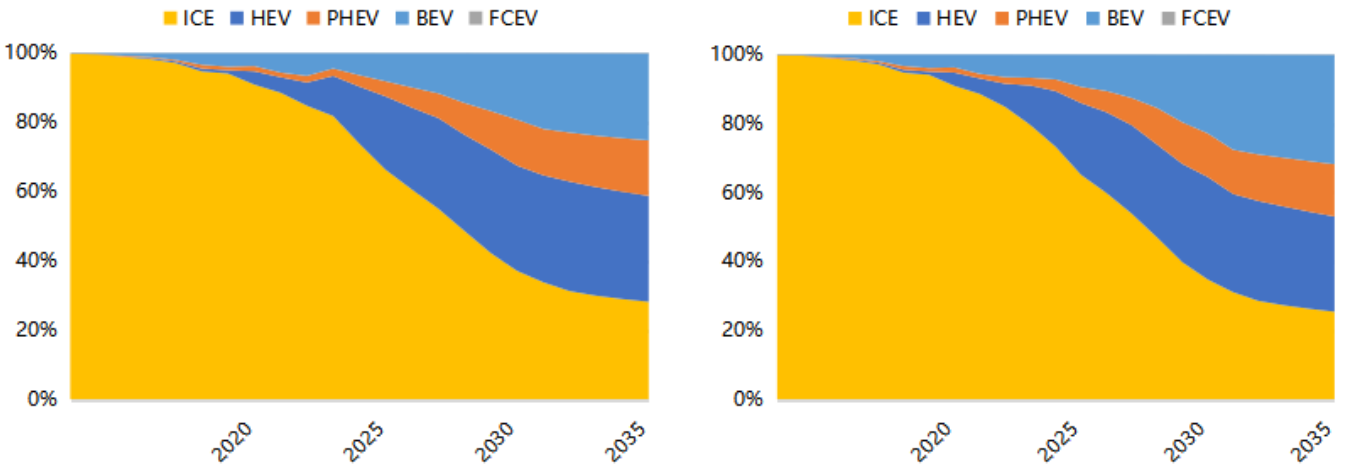

Fig. 2. Forecast for the proportion of passenger car sales for each technical route under no policy and green tax policy.

\subsection{Evaluation on energy saving and environmental protection effect.}

Calculate energy saving and emission reduction effects based on the sales forecast results of each technical route under the green tax scheme. First of all, it is necessary to judge the trend of vehicle energy consumption, mileage of passenger cars and pollutant emissions of single vehicle.

\subsubsection{Judgment of vehicle energy consumption}

With reference to the fuel consumption target of each model proposed in the "Energy-saving and New Energy Vehicle Technology Roadmap 2.0, the roadmap sets, by 2035 , the power consumption of battery electric vehicles should reach $10 \mathrm{kWh} / 100 \mathrm{~km}$, The fuel consumption of plug-in hybrid electric vehicles in the power maintenance mode should not exceed $3.8 \mathrm{~L} / 100 \mathrm{~km}$, the fuel consumption of internal combustion engine vehicles should reach $5.7 \mathrm{~L} / 100 \mathrm{~km}$ and the fuel consumption of hybrid electric vehicles should reach $4 \mathrm{~L} / 100 \mathrm{~km}$.

Based on research and investigation, CATARC believed that the hydrogen consumption of fuel cell electric vehicles will steadily drop from $1 \mathrm{~kg} / 100 \mathrm{~km}$ in the future. By referring to the above setting, the fuel consumption rate of each vehicle technology route is set to the target value of the corresponding year, and the forecast results of vehicle fuel consumption before 2035 are as follows:

Table 3. Forecast for energy consumption of passenger cars by technical routes.

\begin{tabular}{|c|c|c|c|c|}
\hline Model & Energy consumption unit & $\mathbf{2 0 2 5}$ & $\mathbf{2 0 3 0}$ & $\mathbf{2 0 3 5}$ \\
\hline ICEV & $\begin{array}{c}\text { Fuel consumption per } \\
\text { 100km }\end{array}$ & 6.3 & 5.7 & 5.7 \\
\hline
\end{tabular}

\begin{tabular}{|c|c|c|c|c|}
\hline Model & Energy consumption unit & 2025 & 2030 & 2035 \\
\hline HEV & $\begin{array}{c}\text { Fuel consumption per } \\
100 \mathrm{~km} \\
(\mathrm{~L} / 100 \mathrm{~km} \text {; WLTC })\end{array}$ & 5.3 & 4.5 & 4 \\
\hline $\mathrm{BEV}$ & $\begin{array}{c}\text { Power consumption } \\
\text { per } 100 \mathrm{~km} \\
(\mathrm{kWh} / 100 \mathrm{~km} ; \mathrm{CLTC})\end{array}$ & 11 & 10.5 & 10 \\
\hline PHEV & $\begin{array}{l}\text { Fuel consumption in } \\
\text { power maintenance mode } \\
(\mathrm{L} / 100 \mathrm{~km} \text {; WLTC) }\end{array}$ & 4.3 & 4 & 3.8 \\
\hline FCEV & $\begin{array}{l}\text { Hydrogen consumption } \\
\text { per } 100 \mathrm{~km}(\mathrm{~kg} / 100 \mathrm{~km})\end{array}$ & 0.92 & 0.86 & 0.8 \\
\hline
\end{tabular}

Data Source: Energy-saving and New Energy Vehicle Technology Roadmap 2.0, CATARC

\subsubsection{Judgment of mileage}

The current mobility rules of electric vehicles and traditional vehicles in China are basically same and they mainly focus on commuting short-distance mobility. Especially, the average daily mileage of pure electric private cars, official cars and taxis are $37 \mathrm{~km}, 55 \mathrm{~km}$ and $202 \mathrm{~km}$. Considering that the passenger car market is dominated by private cars, the average daily mileage of $37 \mathrm{~km}$ is selected to calculate the annual mileage of $13,500 \mathrm{~km}$

\subsubsection{Judgment of pollutant emissions}

The passenger car pollutant emission factors are calculated by referring to the calculations of automobile pollutant emissions showed in the Annual Report on China Mobile Source Environmental Management (2019) released by the Ministry of Ecology and Environment. The emissions of various pollutants are as follows:

Table 4. Pollutant emission factors of single passenger car.

\begin{tabular}{|c|c|c|c|c|c|}
\hline Model & $\begin{array}{c}\text { CO emission from a } \\
\text { single car } \\
\text { (kg/car/year) }\end{array}$ & $\begin{array}{c}\text { HC emission } \\
\text { from a single car } \\
\text { (kg/car/year) }\end{array}$ & $\begin{array}{c}\text { NOX emission } \\
\text { from a single car } \\
\text { (kg/car/year) }\end{array}$ & $\begin{array}{c}\text { PM emission } \\
\text { from a single car } \\
\text { (kg/car/year) }\end{array}$ & $\begin{array}{c}\text { Total emissions from } \\
\text { a single car } \\
\text { (kg/car/year) }\end{array}$ \\
\hline $\begin{array}{c}\text { Passenger } \\
\text { car }\end{array}$ & 80.746 & 8.092 & 2.827 & 0.025 & 91.689 \\
\hline
\end{tabular}




\subsubsection{Evaluation}

Considering the reduction in fuel consumption caused by the replacement of new energy vehicles and the improvement in fuel-saving ability of internal combustion engine vehicles and hybrid electric vehicles, under the background of the green tax system, it is expected that the number of new energy vehicles in 2025/2030/2035 will exceed 12 million/ 39 million / 83 million. Meanwhile, 10 million $\mathrm{T} / 39$ million $\mathrm{T} / 59$ million $\mathrm{T}$ fuel will be saved, and 110 thousand $\mathrm{T} / 357$ thousand $\mathrm{T} / 761$ thousand $\mathrm{T}$ pollutant emissions will be reduced.

\section{Conclusion}

\subsection{The green tax system for automobile products is conducive to boosting the promotion of energy-saving and new energy vehicles.}

As mentioned above, the green tax system for automobile products is designed based on fuel consumption levels. It will reduce the comprehensive tax rate at the purchase stage, so as to reduce their purchase costs of low-fuelconsumption models. At the same time, it will increase the comprehensive tax rate of high-fuel-consumption models at the purchase stage, so as to increase their purchase costs. Thus, it will play the role of regulating consumption. Under the influence of the policies, the proportion of NEVs in terms of sales in 2025/3030/2035 will increase by $1.6 / 2.5 / 5.8$ percentage points. So, the policies have obvious effect on promoting energy-saving and new energy vehicles.

\subsection{The green tax system for automobile products is conducive to promoting energy conservation and emission reduction in the automobile industry.}

On one hand, the improvement of the market share of energy-saving and new energy vehicles will reduce petrochemical energy consumption. On the other hand, it will directly reduce carbon emissions from in-use vehicles. As mentioned in this article, under the background of the green tax system, it is expected that 10 million $\mathrm{T} / 39$ million $\mathrm{T} / 59$ million $\mathrm{T}$ fuel will be saved, and 110 thousand $\mathrm{T} / 357$ thousand $\mathrm{T} / 761$ thousand $\mathrm{T}$ pollutant emissions will be reduced in 2025/2030/2035. So, the policies have obvious environmental benefits.

\section{References}

1. Yang Ping. Thoughts on Promoting the Construction of Green Tax System in China [J].Business Information. 2019(10), 112-113.

2. Strategic Advisory Committee on Energy Saving and New Energy Vehicle Technology Roadmap \& China Society of Automotive Engineers. Energy-saving and New Energy Vehicle Technology Roadmap 2.0 [M]. Beijing: China Machine Press,2020.
3. China EV100. Top-level Design and Strategic Collaboration for Automotive Revolution [R/OL]. (2019-01-10) [2020-01]. http://www.ev100plus.com/content/details970_1118. html.

4. Ministry of Environmental Protection of the People's Republic of China. Annual Report on China Mobile Source Environmental Management (2019) [R/OL]. (2019-09-04) [2020-01]. http://www.mee.gov.cn/hjzl /sthjzk/ydyhjgl/. 